World Lumen Congress 2021 | May 26-30, 2021 | lasi, Romania

\title{
How Efficient are the Romanian Sports Federations? A Theoretical and Experimental Approach
}

\author{
Constanta-Valentina MIHAILA, Gabriela Alina \\ PARASCHIVA, Laurentiu Mihai MIHAILA
}

\author{
https://doi.org/10.18662/wlc2021/44
}

How to cite: Mihaila, C.-V., Paraschiva, G.A., \& Mihaila, L.M. (2021). How Efficient are the Romanian Sports Federations? A Theoretical and Experimental Approach. In A. Sandu (vol. ed.), Lumen Proceedings: Vol. 17 World Lumen Congress 2021 (pp. 437-446). Iasi, Romania: LUMEN Publishing House. https://doi.org/10.18662/wlc2021/44 


\title{
How Efficient are the Romanian Sports Federations? A Theoretical and Experimental Approach
}

\author{
Constanta-Valentina MIHAILA1, Gabriela Alina PARASCHIVA2, \\ Laurentiu Mihai MIHAILA ${ }^{3}$
}

\begin{abstract}
Examining the links between performance and financial issues has been, and still is, subject of a great number of researches both in the business and in the non-profit environment. In this respect, the world of sports has not been bypassed either, using concepts and / or instruments from accounting, economics or statistic areas in order to analyse a firm or an NGO in the sport industry and his success. The present study represents one of the first attempt to value the Romanian sports federations' activity which is not based solely on the scores attained following places and medals won by atbletes participating in the national and international competition system. And it is intended to identify an appropriate methodology to highlight how efficient the sports federations have been in 2019 year, reporting the results obtained to the resources used, from a domestic perspective (meaning the participation in national sports events and the scores obtained). This paper addresses 12 Romanian sports federations (out of 75 federations on sport branches) and their efficiency, through the lens of several input, output and outcome indicators, using public data gathered from various sources - the Romanian Ministry of Finance, the National Institute of Statistics, the Romanian Ministry of Youth and Sports. Using statistical tools, such as Spearman rank correlation, as well as statistical methods, such as standardization, we developed an efficiency calculation methodology, which could be used to support managerial team to improve and / or reshape federations' activities, if necessary.
\end{abstract}

Keywords: sports federations, efficiency calculation methodology, management.

\footnotetext{
1 Lecturer, National University of Physical Education and Sports, Faculty of Physical Education and Sport, Bucharest, Romania; constanta.mihaila@unefs.ro

${ }^{2} \mathrm{PhD}$. Student, Politehnica University Timisoara, Faculty of Management in Production and Transportation, Timisoara, Romania; gabriela.paraschiva@student.upt.ro

${ }_{3}^{3} \mathrm{PhD}$. Student, Valahia University, Targoviste, Romania; laurentiumihaila@yahoo.com
} 


\section{Introduction}

Examining the links between performance and financial issues has been, and still is, subject of a great number of researches both in the business and in the non-profit environment. In this respect, the world of sports has not been bypassed either, using concepts and / or instruments from accounting, economics or statistic areas in order to analyze a firm in the sport industry and his success.

In line with this perspective, under the EU Work Plan for Sport 2014-2017, Eurostat with the European Commission's Directorate General for Education and Culture (DG EAC) has initiated in 2016 the regular dissemination of harmonized statistics on sport, covering: (1) employment in sport, (2) international trade in sporting goods, (3) attendance at live sports events and (4) private expenditure on sporting goods and services (Eurostat, 2016). However, in the second initiative from 2018, the last aspect was replaced by active engagement in sport and physical activity (Eurostat, 2018), as an attempt to have a more nuanced perspective, the health and social aspects being also pursued, along with the economic one. Subsequent, in the last years the prospects for sport have been diversified, through new insights such us: volunteering activities and the cultural environment in which they take place, so that sport and event managers better understand the motives and experiences of volunteers (Hallmann \& Fairley, 2018); social return on investment (SROI) in sport, in order to measure and value the wider benefits of sport (in terms of improved health, reduced crime, improved education and enhanced subjective well-being) to society (Davies et al., 2019); corporate social responsibility and reporting applied to the sports world (Valeri, 2019).

So, we decided to develop a three-stage efficiency analysis of the Romanian sports federations, with elements that combine economic and social aspects. This paper is devoted to the first stage of the efficiency analysis, to the year 2019 (as this is the one for which the data are currently available) and to twelve national sports federations. It will present the methodology we developed on how efficient the sports federations have been, reporting the results obtained to the resources used, from a domestic perspective (meaning the participation in national sports events and the scores obtained), using public data gathered from various sources - the Romanian Ministry of Finance (MF), the National Institute of Statistics (INS), the Romanian Ministry of Youth and Sports (MTS). The methodology could be used as a tool to support managerial teams to improve and / or reshape federations' activities, if necessary. 
The selection of the twelve national sports federations was determined by the results of a previous research, part of the doctoral thesis entitled Efficient management - a favoring factor for improving sports results at the level of school sports club, which performed the hierarchy of all the 47 sports disciplines organized in pre-university sports education in Romania, out of 51 possible (Mihaila, 2021). Thus, we decided to select the national sports federations that corresponds to the sports disciplines organized in most of the pre-university sport structures.

As they combine economic and social prospects, we selected the following seven aspects for analysis: (1) the number of affiliated sports structures, as input; (2) the number of legitimated athletes, as input; (3) the number of staff for activities without patrimonial purpose, as input; (4) the level of revenues per person from activities without patrimonial purpose, as input (this is a compound indicator, calculated as the ratio between the total level of income and the number of legitimated athletes); (5) the number of sports structures participating in the national competition system, as output; (6) the number of athletes participating in the national competition system, as output; (7) the scores attained following places and medals won by athletes participating in the national competition system, as identified outcome.

Therefore, this present paper will provide answers to the following questions: Q1 - Are there any correlations between the input elements and the output and outcome elements established for national sports federations? and Q2 - Can an efficiency calculation methodology be developed?

Compared to the methodology developed on Belgian sports federations by Winand et al. (2012), or with the one developed on United Kingdom's national nonprofit sport federations by Omondi-Ochieng (2021) which are focused on financial performance, we included in the analysis area aspects related to territorial ramifications and aspects of participation in competitions (i.e. elements regarding sports for all and elite sports), but we kept financial issues on a general level (only in terms of income, not in terms of expenses / investments in sports for all and elite sports).

\section{Research methodology}

Methodologically, in order to answer to the research questions, it was first developed a desk research analysis on the following:

- the level of revenues from activities without patrimonial purpose and the number of staff for activities without patrimonial purpose, for 
twelve national sports federations; were used public information available on the website of MF, section Tax information and balance sheets (Ministry of Finance, n. d.);

- the number of sports structures and the number of legitimated athletes; were used public information gathered by INS and available within the TEMPO Database - time series, Social Statistics data (A) for the field of Sports (A10) (National Institute of Statistics);

- cross-checking and validation of the previous findings regarding the number of sports structures and the number of legitimated athletes, using public information provided by MTS in the Sports Yearbook, 2019 edition (last with updated data) (Ministry of Youth, 2019);

- the number of the sports structures and athletes participating in the national competition system, using public information provided by MTS in the Sports Yearbook, 2019 edition (last with updated data), (Ministry of Youth, 2019);

- the scores attained following places and medals won by athletes participating in the national competition system, using public information provided by MTS in the Sports Yearbook, 2019 edition (last with updated data) (Ministry of Youth, 2019).

After the data were collected and verified, we proceeded to the second step of the analysis, performing Spearman rank correlation tests in SPSS for six of the seven aspects above; the null hypothesis (H0) was set as "there is no correlation between the two variables", the alternative hypothesis (H1) was set as "there is a significant correlation between the two variables" and the significance threshold was $\mathrm{p}=.05$. The seventh aspect, namely the scores attained following places and medals won by athletes participating in the national competition system, is from the start a compound one, obtained through a specific methodology of MTS, which takes into account both participation and its value; therefore, correlation tests were not considered necessary.

Then we proceeded to the third step, standardization: all the variables that proved to be correlated were subject to standardization in order to design two composite indicators: results, as the arithmetic mean of normalized output and outcome variables; and resources, as the arithmetic mean of normalized input variables. And finally, we calculated an efficiency index, as a ratio between results and resources, with the following meaning; at a value equal to 1 , the index indicates that the results obtained are at the level of those expected; a value above 1 indicates that the results obtained are better than those expected, in relation to the available resources; and a 
value below 1 indicates that the results obtained are weaker than those expected, in relation to the available resources (and that improvement processes would be needed).

\section{Results and conclusions}

Regarding the identification of possible correlations between the established variables, the results are presented in a matrix format, with values for each possible correlation (including the correlations of variables with themselves, which always takes the value 1). The results presented in Table 1 - Spearman rank correlation tests, show that:

- all $\mathrm{p}$ values recorded in column $\mathrm{F}$ (the variable number of staff) are above .05; means that we reject the alternative hypothesis (H1) and that the (input) variable "number of staff" does not significantly correlate with any of the other variables;

- not all the $\mathrm{p}$ value recorded in column $\mathrm{C}$ (the variable "number of sports structures participating in the national competition system") are below .05; although for the variable "level of revenues per person" the correlation coefficient takes the value $r=-.573$, we have a significance value $\mathrm{p}=.051$; means that, in this case only, we reject the alternative hypothesis (H1) and that there is no significant correlation between the variable "level of revenues per person" and the variable "number of sports structures participating in the national competition system"; yet, for the (input) variable "level of revenues per person" and the (output) variable "number of athletes participating in the national competition system", we found a correlation coefficient $r=-.720$ and a significance value $p=.008$; means that, in this case, we reject the null hypothesis $(\mathrm{H} 0)$, and that these two input and output variables are significantly correlated;

- all other variables correlate, with the significant level below .05 or below .01.

Table 1 - Spearman rank correlation tests

\begin{tabular}{ll|r|r|r|r|r|r}
\hline Spearman's rho & \multicolumn{1}{c|}{ A } & \multicolumn{1}{c|}{ B } & \multicolumn{1}{c|}{ C } & \multicolumn{1}{c|}{ D } & \multicolumn{1}{c|}{ E } & \multicolumn{1}{c}{ F } \\
\hline $\begin{array}{l}\text { A. level of revenues } \\
\text { per person }\end{array}$ & $\begin{array}{l}\text { Correlation } \\
\text { Coefficient } \\
\text { Sig. }(2-\end{array}$ & 1.000 & $-.643^{*}$ & -.573 & $-.923^{* *}$ & $-.720^{* *}$ & -.077 \\
& \begin{tabular}{l} 
tailed) \\
\cline { 2 - 8 }
\end{tabular} &. & .024 & .051 & .000 & .008 & .811 \\
\hline
\end{tabular}




\begin{tabular}{|c|c|c|c|c|c|c|c|}
\hline & $\begin{array}{l}\text { number of } \\
\text { affiliated sports } \\
\text { structures }\end{array}$ & $\begin{array}{l}\text { Correlation } \\
\text { Coefficient } \\
\text { Sig. }(2- \\
\text { tailed) } \\
\mathrm{N} \\
\end{array}$ & $\begin{array}{r}\cdot \\
12 \\
\end{array}$ & $\begin{array}{r}.937^{* *} \\
.000 \\
12 \\
\end{array}$ & $\begin{array}{r}.734^{* *} \\
.007 \\
12 \\
\end{array}$ & $\begin{array}{r}.727^{* *} \\
.007 \\
12 \\
\end{array}$ & $\begin{array}{r}.310 \\
.327 \\
12 \\
\end{array}$ \\
\hline C. & $\begin{array}{l}\text { number of sports } \\
\text { structures } \\
\text { participating in the } \\
\text { national } \\
\text { competition } \\
\text { system }\end{array}$ & $\begin{array}{l}\text { Correlation } \\
\text { Coefficient } \\
\text { Sig. }(2- \\
\text { tailed) } \\
\text { N }\end{array}$ & & 1.000 & $\begin{array}{r}.692^{*} \\
.013 \\
12\end{array}$ & $\begin{array}{r}.713^{* *} \\
.009 \\
12\end{array}$ & $\begin{array}{r}.359 \\
.252 \\
12\end{array}$ \\
\hline D. & $\begin{array}{l}\text { number of } \\
\text { legitimated } \\
\text { athletes }\end{array}$ & $\begin{array}{l}\text { Correlation } \\
\text { Coefficient } \\
\text { Sig. }(2- \\
\text { tailed) } \\
\mathrm{N} \\
\end{array}$ & & & $\begin{array}{r}\cdot \\
12 \\
\end{array}$ & $\begin{array}{r}.853^{* *} \\
.000 \\
12 \\
\end{array}$ & $\begin{array}{r}.232 \\
.467 \\
12 \\
\end{array}$ \\
\hline E. & $\begin{array}{l}\text { number of } \\
\text { athletes } \\
\text { participating in the } \\
\text { national } \\
\text { competition } \\
\text { system }\end{array}$ & $\begin{array}{l}\text { Correlation } \\
\text { Coefficient } \\
\text { Sig. }(2- \\
\text { tailed) } \\
\text { N }\end{array}$ & & & & 12 & $\begin{array}{r}.408 \\
.187 \\
12\end{array}$ \\
\hline & number of staff & $\begin{array}{l}\text { Correlation } \\
\text { Coefficient } \\
\text { Sig. }(2- \\
\text { tailed) } \\
\mathrm{N} \\
\end{array}$ & & & & & 1.000 \\
\hline
\end{tabular}

Source: authors own development using SPSS processing

In this moment we are able to respond to Q1, the first research question, regarding correlations between the input elements and the output and outcome elements established for national sports federations: except "number of staff", among all the other elements statistically significant correlations were identified.

Therefore, we decided to exclude the (input) variable "number of staff" from the third step, standardization, but to keep the (input) variable "level of revenues per person" (due to the significant statistic correlation with the (output) variable "number of athletes participating in the national competition system"). 
We began the standardization with the three remaining input variables and with three output/ outcome variables, initially calculating their $z$-scores values. As some of the measured values for variables were quite large and uncommon relative to the norm, unusual $z$-scores were identified ( $z$-scores that are more than 2 standard deviations away from the mean). That is why we decided that a more appropriate standardization would be the Hull ones'. So, using Hull Score $=50+$ (z-score x 14), we converted all the z-scores into Hull Scores (the results are presented in Tables 2 and 3).

Table 2 - Hull scores for the input variables

\begin{tabular}{c|c|c|c}
\hline Sport federation & $\begin{array}{c}\text { Hull_level of } \\
\text { revenues per } \\
\text { person }\end{array}$ & $\begin{array}{c}\text { Hull_number of } \\
\text { affiliated sports } \\
\text { structures }\end{array}$ & $\begin{array}{c}\text { Hull_number of } \\
\text { legitimated athletes }\end{array}$ \\
\hline Football Federation & 36.45808 & 94.18218 & 93.17824 \\
\hline Athletics Federation & 41.32574 & 46.66114 & 46.40718 \\
\hline Handball Federation & 45.19926 & 47.11502 & 46.64798 \\
\hline Volley-ball Federation & 43.54642 & 45.78824 & 44.96238 \\
\hline Basket-ball Federation & 36.00686 & 47.39432 & 56.3 \\
\hline Judo Federation & 47.49148 & 45.8406 & 45.05786 \\
\hline Fighting Federation & 53.80604 & 45.89296 & 44.90694 \\
\hline $\begin{array}{c}\text { Swimming and Modern } \\
\text { Pentathlon Federation }\end{array}$ & 39.67724 & 45.19464 & 45.10322 \\
\hline Tennis Federation & 49.3798 & 49.38456 & 44.85304 \\
\hline Rugby Federation & 59.83738 & 44.44396 & 44.7577 \\
\hline Table tennis Federation & 61.48924 & 44.61854 & 43.938 \\
\hline Gymnastics Federation & 85.78232 & 43.4837 & 43.88718 \\
\hline Source:
\end{tabular}

Source: authors own development using SPSS processing

Therefore, although initially it was not foreseen as such, we achieved a Hull normalization of the initial values. It should be noted that the distribution of the scores will always remain the same, regardless of whether the $\mathrm{z}$-scores or the Hull scores are used.

Table 3 - Hull scores for the output and outcome variables

\begin{tabular}{c|c|c|c}
\hline Sport federation & $\begin{array}{c}\text { Hull_number of } \\
\text { sports structures } \\
\text { participating in the } \\
\text { national } \\
\text { competition } \\
\text { system }\end{array}$ & $\begin{array}{c}\text { Hull_number of } \\
\text { athletes } \\
\text { participating in the } \\
\text { national } \\
\text { competition } \\
\text { system }\end{array}$ & $\begin{array}{c}\text { Hull_scores } \\
\text { attained by } \\
\text { participating in the } \\
\text { national } \\
\text { competition } \\
\text { system athletes }\end{array}$ \\
\hline Football Federation & 94.42508 & 94.39246 & 40.53516 \\
\hline Athletics Federation & 46.47858 & 46.1892 & 79.51116 \\
\hline Handball Federation & 46.17618 & 47.51164 & 41.53084 \\
\hline
\end{tabular}


Constanta-Valentina MIHAILA, et al. | Lumen Proceedings 17 | WLC 2021

\begin{tabular}{c|c|c|c}
\hline Volley-ball Federation & 45.92152 & 46.07188 & 41.41016 \\
\hline Basket-ball Federation & 46.11248 & 47.1013 & 41.6154 \\
\hline Judo Federation & 46.12844 & 45.99684 & 50.85512 \\
\hline Fighting Federation & 46.04094 & 45.71978 & 55.99704 \\
\hline $\begin{array}{c}\text { Swimming and Modern } \\
\text { Pentathlon Federation }\end{array}$ & 45.72272 & 45.48514 & 76.9206 \\
\hline Tennis Federation & 47.07526 & 45.7839 & 42.70166 \\
\hline Rugby Federation & 45.33282 & 45.85124 & 40.96356 \\
\hline Table tennis Federation & 45.42032 & 45.0118 & 41.64858 \\
\hline Gymnastics Federation & 45.16566 & 44.88468 & 46.31072 \\
\hline
\end{tabular}

Source: authors own development using SPSS processing

And because, like the z-score, the Hull-score has no units, it was possible to combine Hull-scores for different variables into a single composite one. So, Table 4 presents the values of two final composite indicators that we designed - results (as the arithmetic mean of normalized Hull output and outcome variables) and resources (as the arithmetic mean of normalized Hull input variables); and the values for an efficiency index, calculated as a ratio between results and resources.

Table 4 - Efficiency index

\begin{tabular}{c|c|c|c}
\hline Sport federation & Results & Resources & Efficiency index \\
\hline Football Federation & 76.4509 & 74.60616667 & 1.02472628 \\
\hline Athletics Federation & 57.39298 & 44.79802 & 1.28114992 \\
\hline Handball Federation & 45.07288667 & 46.32075333 & 0.97306031 \\
\hline Volley-ball Federation & 44.46785333 & 44.76568 & 0.99334698 \\
\hline Basket-ball Federation & 44.94306 & 46.56706 & 0.96512556 \\
\hline Judo Federation & 47.66013333 & 46.12998 & 1.03317047 \\
\hline Fighting Federation & 49.25258667 & 48.20198 & 1.02179592 \\
\hline Swimming and Modern & & & \\
Pentathlon Federation & 56.04282 & 43.32503333 & 1.29354361 \\
\hline Tennis Federation & 45.18694 & 47.87246667 & 0.94390248 \\
\hline Rugby Federation & 44.04920667 & 49.67968 & 0.88666446 \\
\hline Table tennis Federation & 44.0269 & 50.01526 & 0.88026934 \\
\hline Gymnastics Federation & 45.45368667 & 57.71773333 & 0.78751683 \\
\hline
\end{tabular}

Source: authors own development

As can be seen, its calculated values vary between 0.78751683 and 1.29354361 (for accuracy, 8 digits after the decimal were kept). Considering the twelve Romanian sports federations as a cluster and taking strictly into account their corresponding values of the established indicators, it results that: 
- 6 federations, out of 12 , have the efficiency index values slightly above 1 (Judo Federation, Fighting Federation and Football Federation), or slightly below 1 (Volley-ball Federation, Handball Federation and Basket-ball Federation); because a variation of .05 around 1 is insignificant, we conclude that for all these 6 federations the results were at the level of those expected;

- 2 federations, out of 12, have the efficiency index values well over 1 (Swimming and Modern Pentathlon Federation and Athletics Federation); in their case, we conclude that the results were better than those expected, in relation to the available resources;

- 4 federations, out of 12 , have the efficiency index values below 1(Tennis Federation, Rugby Federation, Table tennis Federation and Gymnastics Federation); in their case, we conclude that the results were under those expected, in relation to the available resources;

- a hierarchy of the 12 sports federations can be achieved, from the most efficient one (Swimming and Modern Pentathlon Federation) to the less efficient one (Gymnastics Federation).

And with these results, we provided an answer to the second research question, regarding the possibility to develop a methodology for the efficiency of sports federations. From this perspective, in order to increase the level of efficiency without diminishing resources, means that the management team of a federation should increase the values of the result indicators - level of participation in the national competition system structures and athletes, level of scores attained following places and medals won in the national competition system.

However, the efficiency index is a dynamic indicator, its value being very sensitive to any changes made in the database, such as for example the addition / deletion of some records (cases). Therefore, for this first attempt to analyze the efficiency of sports federations, the intrinsic values of the efficiency index are of little significance, what prevails being the methodology itself and how it should be understood the values obtained. Expanding the database to all 75 federations by sports branches, for the next research stage, will lead to the creation of a complete cluster of cases and to the calculation of the final efficiency index values.

\section{References}

Davies, L. E., Taylor, P., Ramchandani, G., \& Christy, E. (2019). Social return on investment (SROI) in sport: a model for measuring the value of participation in England. International Journal of Sport Policy and Politics, 11(4), 585-605. http://doi.org/10.1080/19406940.2019.1596967 
Eurostat. (2016). Sport Statistic - Compact guides, 2016 edition.

http://doi.org/10.2785/535276

Eurostat. (2018). Sport Statistic - Compact guides, 2018 edition. (DOI): 10.2785/167456, https://ec.europa.eu/eurostat/web/products-catalogues/-/ks-07-17-123

Hallmann, K., \& Fairley, S. (Eds.). (2018). Sports Volunteers around the Globe. Meaning and Understanding of Volunteering and its Societal Impact. Springer. https://doi.org/10.1007/978-3-030-02354-6

Mihaila, C. V. (2021). Efficient management - a favoring factor for improving sports results at the level of school sports club. [Doctoral thesis abstract, Doctoral School of National University of Physical Education And Sports, Bucharest]. Scoala Doctorala UNEFS. http://scoaladoctoralaunefs.ro/wpcontent/uploads/2021/02/Abstract ENGLEZA-BURCEAMIHAILA.pdf

Ministry of Finance. (n.d.). Informații persoane juridice selecţie nume și județ [Information legal entities selection name and county]. https://mfinante.gov.ro/ro/web/site/info-pj-selectie-nume-si-judet;

Ministry of Youth. (2019). Anuarul Sportului [Sports Yearbook]. http://mts.ro/wpcontent/uploads/2017/09/Anuarul-Sportului-2019.pdf

National Institute of Statistics. (n.d.). http://statistici.insse.ro/shop/

Omondi-Ochieng, P. (2021). Financial performance of the United Kingdom's national nonprofit sport federations: a binary logistic regression approach. Managerial Finance, 47(6), 868-886. https://doi.org/10.1108/MF-03-2020$\underline{0126}$

Valeri, M. (2019). Corporate social responsibility and reporting in sports organizations. Springer. https://link.springer.com/content/pdf/10.1007\%2F978-3-31997649-5.pdf

Winand, M., Zintz, T., \& Scheerder, J. (2012). A financial management tool for sport federations. Sport, Business and Management: An International Journal, 2(3), 225-240. http://doi.org/10.1108/20426781211261539 